\title{
Oldest record of a bisexual plant
}

W e have discovered coalescent male and female gametangia in fossils of the earliest charophytes (one of the algal groups most closely related to higher plants) from the Devonian period. This provides the oldest evidence of bisexuality in plants. In contrast to the well-documented complex evolution of the female reproductive organs (the oogonia), these fossils demonstrate that, in charophytes, the structure of the male sex organs (antheridia) has remained relatively unchanged to the present day.

The extensive fossil record of the charophytes since the Late Silurian period is based almost exclusively on female fructifications ${ }^{1}$. Material from Landeyran Quarry, near Cessenon on the southern margin of the French Massif Central, is unusual in that it exhibits reproductive organs of both sexes. Charophytes are commonly found in dolomitic rock sequences in this area, indicating past intertidal to supratidal conditions ${ }^{2}$ and suggesting that the plants tolerated fluctuating salinity as does the extant genus Lamprothamnium J. Groves (Characeae). Associated conodonts indicate that the plants are 405 million years old (Early Lochkovian age; Postwoschmidti zone) $)^{3}$.

The Landeyran charophytes represent a single taxon. They consist of spheres $0.6-1.1 \mathrm{~mm}$ in diameter. The original cellular structures, diagenetically replaced by haematite, show excellently preserved surface characters, especially numerous external moulds of antheridia (Fig. 1). Although the disposition of sexes is different from extant forms, these moulds show a similarly complex structure, that is, spherical bodies composed of imbricated triangular plates, each bearing a central pillar (manubrium) on its internal face where the spermatogenous filaments are inserted.

In the fossil material, the antheridia are borne by two ramified axes, symmetrical about the dorsoventral plane of the fructification. The oogonium, whose multicellular wall is visible in thin section, occupies all of the interior. This structure, consisting of an oogonium surrounded by fertile axes bearing antheridia, represents a utricle, similar to that developed in the Cretaceous Clavatoraceae Perimneste Harris. However, in the Cretaceous form the symmetry of the utricle is tripartite ${ }^{1}$.

In its bilaterality, the Landeyran species is similar to the mid-Devonian Pinnoputamen Wang and $\mathrm{Lu}$, in which the utricles also have two ramified, opposite branches at their surface, but lack antheridia. Despite these resemblances, it would be inadvisable to assign the Landeyran species to a definite group, in the absence of data on the disposition and number of gyrogonite cells. Heterogamy in land plants is attested by spore

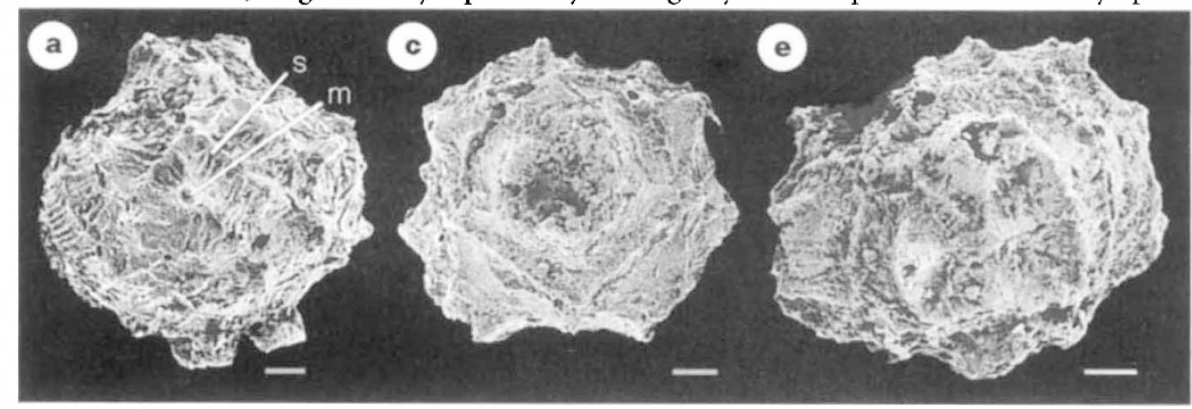

b

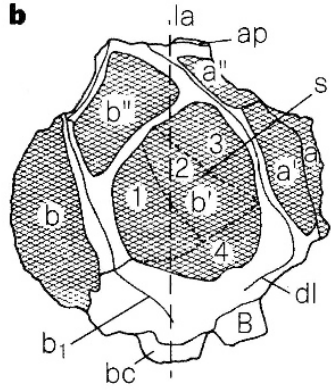

d

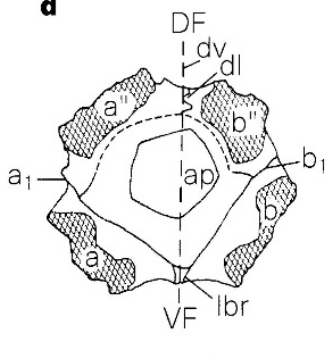

$\mathbf{f}$

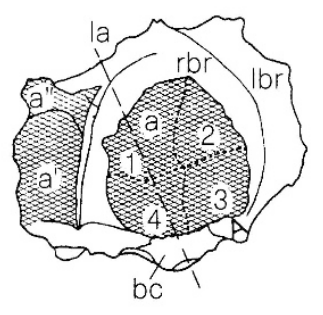

Figure 1 Utricles of a Devonian bisexual charophyte. a, Lateral view, showing the left branch bearing three antheridia and $b$, a reconstruction. $c$, Apical view and $d$, a reconstruction. $e$, Lateral view of the right side, showing lower large antheridial imprints borne on the right lateral branch and the ventral bracteas, and $\mathrm{f}$, a reconstruction. $\mathrm{s}$, antheridial shield; $\mathrm{m}$, manubrium scar; $\mathrm{A}$, basal cell of the right branch; $a_{1}$, right branch; $a, a^{\prime}, a^{\prime \prime}$, lower, middle and upper right antheridia, respectively; $B, b_{1}, b, b^{\prime}, b^{\prime \prime}$, same nomenclature for the left branch; ap, apical pore of the gyrogonite; bc, basal cell; DF, dorsal face; dl, dorsal line; dv, dorsoventral symmetrical plane; la, longitudinal axis; lbr, left bractea; rbr, right bractea; VF, ventral face; $1-4$, the four shields of the left antheridium. Scale bars, $100 \mu \mathrm{m}$. tetrads displaying evidence of meiosis as early as the mid-Ordovician ${ }^{4}$, but distinct male and female gametangia are not known earlier than the Pragian Rhynie Chert ${ }^{5}$, five million years younger than the Landeyran occurrence. With regards to bisexuality, the oldest land plants bearing both male and female reproductive organs are the Late Devonian lycophytes ${ }^{6}$. So the Landeyran charophytes represent the oldest record of heterogamy and bisexuality.

Monique Feist, Raimund Feist

Institut des Sciences de l'Evolution (CNRS, UMR 5554),

Université Montpellier-2, Place Bataillon,

34095 Montpellier Cedex 05, France

e-mail:mofeist@isem.univ-montp2.fr

\section{Grambast, L. Taxon 23, 463-481 (1974).}

2. Feist, R. Cour. Forsch. Inst. Senckenberg 75, 331-352 (1985).

3. Feist, R. \& Schönlaub, H. P. Neues Jb. Geol. Paläontol. Mh. 4, 200-219 (1974).

4. Gray, I. in Pollen and Spores Systemat. Assoc. Spec. Vol. 44 (eds Blackmore, S. \& Barnes, S. H.) 49-97 (Clarendon, Oxford, 1991). . Rice, C. M. et al. J. Geol. Soc. Lond. 152, 229-250 (1995).

6. Cleal, C. J. in The Fossil Record 2 (ed. Benton, M. J.) 779-794 (Chapman \& Hall, London, 1995).

\section{Blindsight in normal}

\section{subjects?}

Blindsight ${ }^{\mathrm{i}}$ is the condition in which patients with damage to the visual cortex of the brain nonetheless have residual visual sensitivity ${ }^{2}$ in a subjectively blind part of the visual field. Kolb and Braun report ${ }^{3}$ an intriguing parallel to blindsight in normal subjects, who were briefly shown a pattern in which part of one quadrant of the display had a contrasting texture, which 'popped out' from the rest of the pattern. When this texture pattern, viewed by one eye, was masked by a complementary pattern in the other eye, the subjects' ratings of subjective confidence in their ability to detect the texture contrast showed no correlation with their success rate, whereas in the unmasked condition their confidence was highly related to their success rate.

We have reproduced Kolb and Braun's procedure as closely as possible using target quadrants defined by orientation, but did not find blindsight. Performance was better in the unmasked than in the masked condition, and there was a high correlation of confidence with success in both cases. When we altered the exposure durations to obtain comparable performance in the two conditions, success and confidence were still highly correlated (Fig. 1; Table 1).

Observers could identify the unmasked target after exposures of about $100 \mathrm{~ms}$ (followed by a post-stimulus mask), and two of the subjects (A. J. S. M. and J. L.) could also 